\title{
Aging and Senotherapeutics
}

\author{
Ivana Čepelak ${ }^{1}$ (D), Slavica Dodig ${ }^{1}$ \\ ${ }^{1}$ Department of Medical Biochemistry and Hematology, School of Pharmacy and Biochemistry, \\ University of Zagreb, Croatia
}

\begin{abstract}
:
One of the key mechanisms of the aging process of an organism and of the dysfunctionality and chronic diseases related with aging is the so-called cell senescence. It implies irreversible cell cycle arrest that occurs in response to different forms of cellular stress. Senescent cells that accumulate over time are viable, subject to phenotypic changes and excrete different soluble factors, and may affect adjacent cells, resulting in tissue and organ function disorders.

Since old age is an important risk factor for many diseases, the interest of the scientific community is to reduce or avoid the effects of the aging processes. Among numerous developed therapeutic strategies, the development of senotherapeutics (i.e. the targeting strategy) has a significant place and is based on the removal of senescent cells and the abolishment of their adverse effects. Although many questions are still open, based on numerous experimental studies, it is expected that the development of senotherapeutics will contribute to the healthy life of the elderly and the treatment of specific age-related diseases.
\end{abstract}

KEYWORDS: aging; cell senescence; senotherapeutics

\section{SAŽETAK:}

Jedan od ključnih mehanizama procesa starenja organizma i sa starenjem povezanih disfunkcionalnosti i kroničnih bolesti je tzv. stanična senescencija (stanično starenje). Podrazumijeva nepovratni zastoj staničnog ciklusa koji se javlja kao odgovor na različite oblike staničnog stresa. Senescentne stanice koje se tijekom vremena akumuliraju, viabilne su, podliježu fenotipskim promjenama i izlučuju različite topljive čimbenike, te mogu utjecati na susjedne stanice, što rezultira poremećajem funkcije tkiva i organa.

Kako je starosna dob bitan čimbenik rizika za brojne bolesti, ublažavanje ili izbjegavanje učinaka procesa starenja u fokusu je interesa znanstvene zajednice. Među brojnim terapijskim strategijama koje se razvijaju, značajno mjesto zauzima razvoj senoterapeutika, odnosno strategija ciljanja , odnosno ukljanjanja senescentnih stanica i poništavanja njihovih nepovoljnih učinaka. Premda su još uvijek otvorena brojna pitanja, temeljem brojnih eksperimentalnih istraživanja očekuje se da će razvoj senoterapeutika doprinijeti zdravom životnom vijeku starijih osoba kao i tretmanu specifičnih bolesti povezanih sa starenjem.

KLJUČNE RIJEČI: starenje; stanična senescencija; senoterapeutici

\section{OPEN ACCESS}

Correspondence:

Prof. Ivana Čepelak, PhD

ivcepelak@gmail.com orcid.org/0000-0001-7934-599X

This article was submitted to RAD CASA - Medical Sciences as the review article

Conflict of Interest Statement: The authors declare that the research was conducted in the absence of any commercial or financial relationships that could be construed as a potential conflict of interest.

Received: 16 May 2019

Accepted: 24 June 2019

Published: 22 July 2019

Citation:

Cepelak I and Dodig S. Aging and Senotherapeutics. RAD CASA - Medical Sciences. 537=46-47 (2019): 16-24 DOI: $10.21857 / \mathrm{moxpjhglzm}$

Copyright (C) 2019 Cepelak and Dodig.This is an open-access article distributed under the terms of the Creative Commons Attribution License (CC BY). The use, distribution or reproduction in other forums is permit ted, provided the original author(s) and the copyright owners(s) are credited and that the original publication in this journal is cited, in accordance whit accepted adacemic practice. whit accepted adacemic practice. No permitted which does not comply with these terms. 


\section{INTRODUCTION}

The life expectancy of humans has increased significantly over the past few decades and the assumption is that this trend will continue in the future ${ }^{1}$, so the aging process will have an important place in biomedical research. Since many illnesses are associated with the aging process, it is inevitable that they therefore increase the cost of healthcare systems around the world. The common goal and the challenge of a modern society is to ensure healthy aging and the general well-being of people. According to the World Health Organization (WHO) ${ }^{2}$, healthy aging is defined as "the process of developing and maintaining the functional ability that enables wellbeing in older age", hence the ability to meet basic personal needs, to grow, learn and make decisions, to be mobile, to build and maintain relationships, to contribute to society, etc.

What is really aging? Why do we become elderly? How are we getting older? Is aging a disease? Are the diseases associated with aging different from aging? Is aging really inevitable? Can the aging process slow down / stop, or is aging a medical-solving problem? These and other issues are constantly present in each individual's life. Researchers from different fields of science are trying to answer these questions.

One of the aging definitions, which includes all others, states that the aging process is a "progressive, generalized impairment of function that results in a loss of adaptive response to stress and an increasing probability of death" 3 . Undoubtedly, the aging process, depending on the developmental age, is a physiological phenomenon with useful (transformation, adaptation) and adverse consequences, it is a leading risk factor to various pathological conditions. The aging process in some organisms is faster, in some it is slower, but always it is characterized by a reduced body condition and increased risk of dying.

Aging is a multifactorial, complex process, both on a population and on an individual level. Mnemonically, it is well described by abbreviation CUPID (Cumulative, Progressive, Intrinsic, Deleterious $)^{4}$. How aging is a complex process, shows up to now more than 300 evolutionary and mechanistic aging theories, and it is to be expected that there will be new theories. All these theories are trying to explain why and how organisms become elderly. There are different classifications of these theories, but in general they can be divided into a) programmed theories that include genetically programmed aging, among which the best known is the theory of replicative aging, and b) damage theory, with theory of free radicals as the leading theory ${ }^{5,6}$, that includes accumulation of unrepaired proteins, lipids and DNA damaged by free radicals. The central place in this theory have the changes in mitochondria, organelles that are necessary for almost every tissue. It has been shown that mitochondria are involved in various aspects of aging - from the reduction of functions of stem cells to cell senescence ${ }^{7}$. The group of damage theory also includes the so-called "Inflamaging" theory, according to which aging is the result of a continuous low-level inflammatory process during human life $e^{8,9}$.

Since none of the set theories of aging can clarify all aspects of the aging process, a new term - "deleteriome" has recently been introduced. This term implies a measure of the biological age of cells, organs or systems obtained simultaneously by measuring genomic, epigenetic changes, mutations, profiled metabolites and gene expression, which is enabled by the increase of the "omic" fields of research. Thus, the term "deleteriome" links the programmed theories and damage theories ${ }^{10}$.

The results of numerous researches in the field of aging also provided the basis for the development of various therapeutic strategies. The discovery of new compounds that would slow down the aging process, ie prolong the healthy life span and test the potential anti-aging effects of already licensed drugs in the center is of interest to numerous scientists. In the world, a growing number of drug-based companies are established based on one of the set different strategies ${ }^{11}$. The aim of this review is to nearly describe the phenomenon of cellular senescence, one of the supposed causes of aging, and a therapeutic strategy based on this phenomenon. In search of scientific and review papers on the PubMed free search engine, following key words were used: cell senescence, aging, lifespan, senotherapeutics. Articles published in English between 2004 and 2019 were included, and were selected according to relevance to the topic.

\section{HALMARKS OF AGING PROCESS}

The aging process of the organism is reflected in the multiple anatomical and functional characteristics of organisms and organic systems such as cardiovascular, gastrointestinal, oropharyngeal, pulmonary, nervous endocrine, skin, etc. ${ }^{10,12}$. At the molecular level, there are numerous changes as aging process characteristics, such as: a) genomic instability due to the numerous possibilities of DNA damage on the one hand (eg. free radicals, environmental UV-induced mutagens, chemical modifications) and an intrinsic inefficient repair systems of nuclear and mitochondrial DNA, antioxidative enzymes, degradation of damaged DNA and proteins, programmed cell death, etc., on the other hand ${ }^{13}$. b) epigenetic changes such as histone modifications (eg acetylation, phosphorylation) ${ }^{14}$, methylation of DNA, non-coding RNAs, etc. ${ }^{13}$; c) telomeres shortening, whereby the degree of telomeres shortening is in correlation with the risks of diseases associated with the aging ${ }^{15} ; \mathrm{d}$ ) mitochondrial dysfunction resulting in changes in regulation of various signal processes $^{16}$; e) disturbance of clearance and degradation of damaged protein by proteasomes or autophagy ${ }^{17}$; f) derangement of pathways of nutrient recognition including factors such as IGF1 (Insulin like growth factor-1), mTOR (mammalian target of rapamycin) and NAD-dependent sirtuins ${ }^{18,19,20}$; g) stem cell exhaustion; h) reduced regeneration capacity during aging and in age-related diseases ${ }^{21}$; i) changed intercellular communication ${ }^{22}$; j) cellular senescence - one of the basic causes of aging and the most frequently observed hallmark of aging ${ }^{23}$. 
Cell senescence

Cell senescence is a phenomenon / process involved in normal tissue homeostasis, eg. embryonic development and remodeling of tissues ${ }^{23,24}$, and in various age-related pathological conditions ${ }^{25}$, and is also a potent anticancer mechanism, because it limits the replication of pre-neoplastic cells ${ }^{26}$. According to present knowledge, cell senescence implies stable, irreversible stopping of the cell cycle and is induced by the activation of two tumor supressor pathways: p53/p21 and p16INK4a/pRb (retiniblastoma protein $)^{27}$. However, recently, in the scientific literature, there are also in vitro studies that give indications of the possible reversibility of the process of cell senescence or replication ${ }^{28,29}$. As it is assumed for now, this could happen if the cells are in the initial stages of the aging process, i.e. in the state of stopping the cell cycle. Examinations are mostly carried out on tumor cell cultures and for the time being it is not clear what is happening in vivo, so that a further concept of irreversible cell cycle arrest can be considered acceptable.

The process of cell senescence may be caused by various stressors, including mitochondrial dysfunction, telomeric erosion, DNA damage, oxidative stress and other causes. Senescent cells have been morphologically altered (change in volume, change of chromatin organization, i.e. the generation of Senescence-Associated Heterochromatin Foci, SAHF), have increased activity of senescence-associated alpha-galactosidase (SA-alpha-gal) and secrete a large number of proinflammatory cytokines, chemokines, matrix metalloproteinases, MMPs, various growth factors - alltogether referred as proteins secreted into the extracellular space, known as "secretome". Thus, the so-called Senescence Associated Secretory Phenotype (SASP) ${ }^{28}$ is created. These cells may have adverse effects on neighboring cells that are not in the process of senescence, and may even contribute to the creation of tumors and other age-related diseases $^{29,30}$. However, the hallmarks of senescent cells may differ significantly depending on cell type, cell senescence trigger, expression of senescence markers, secretion of different SASP factors, use of different cell apoptotic pathways (Senescent Cell Apoptotic Patways, SCAP), etc. ${ }^{31,32}$.

The secreted pro-inflammatory cytokines further create con-
Reactive metabolites

DNA damage

Dysfunctional telomerase

Proteotoxic stress

Inflammation, DAMPs,

Oncogenes

Mitogens, etc. 


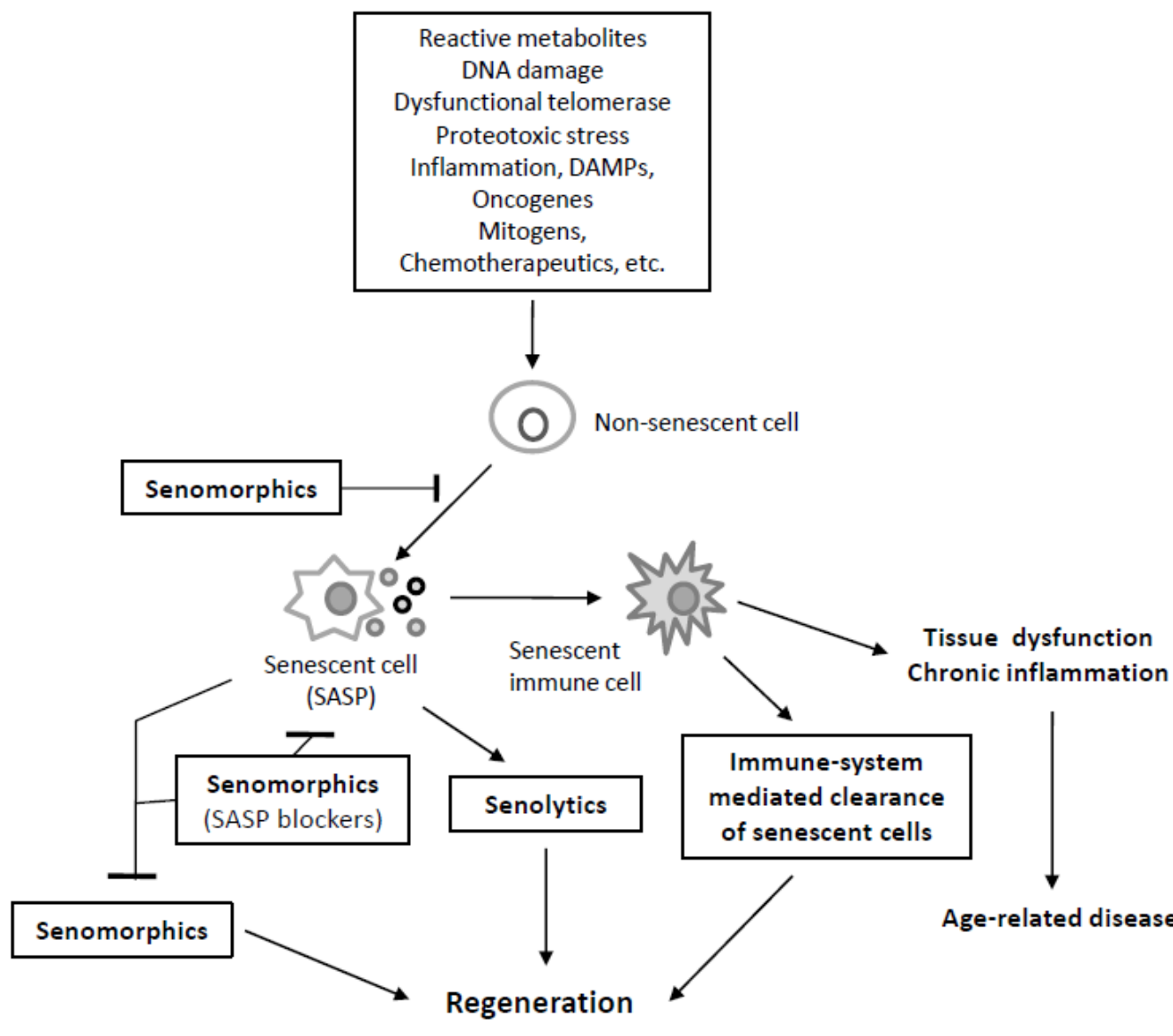

Figure 2. Positions of effects of senotherapeutics. DAMPs - Damage-Associated Molecular Pattern Proteins; Senescence Associated Secretory Phenotype; SASP-Senescence Associated Secretory Phenotype.

include the study of therapeutic potential including antioxidants, telomerase-activating compounds, immunosenscent drugs, nutraceuticals, reprogramming of stem cells, senotherapeutics, autophagy induction, finding the specific presentation of aging-related diseases and integrating of numerous data obtained by" omics" techniques, organ transplants, treatment with stem cells, or young blood/plasma rejuvenation, etc. ${ }^{36,37}$. Investiga- tions of the mentioned anti-aging strategies as well as general research of the aging process are, for the time being, mostly experimental in nature and are mainly focused on aging model systems. Because of moral and ethical principles in human studies, clinical research in literature is significantly less delineated. The general impression is that scientists biogerontologists increasingly perceive that anti-aging strategies directed at one molecule are limited; they consider that the dynamic, networked nature of the life process, which involves transformations and adaptations to survival and health, is at the same time neglected. Therefore, interventions/ strategies that enhance homeodynamics are also considered. These strategies include nutrition, eg. intermittent hunger, Mediterranean diet, phytochemicals, physical and mental activity (common term - hormesis) ${ }^{38}$. One of the more common researach strategies is the development and application of senotherapeutics, that is the main topic of this review.

Table 1. Examples of senolytics and senomorphics and their target molecules/pathways

Compound

Target / Pathway

References

\section{SENOLYTICS}

\begin{tabular}{|c|c|c|}
\hline ABT 737 & BCL-2 family (BCL-2, BCL-XL, BCL-W) & 43 \\
\hline ABT-263 (navitoclax) & BCL-2 family (BCL-2, BCL-XL, BCL-W) & 44 \\
\hline Dasatinib + Quercetin & $\begin{array}{c}\text { Pan-receptor tyrosine kynase / Multiple } \\
\text { pathways }\end{array}$ & 45,46 \\
\hline $\begin{array}{l}\text { Geldanamycin, tenespimycin }(17- \\
\text { AAG })\end{array}$ & HSP90 & 47,48 \\
\hline Fisetin & $\mathrm{PI} 3 \mathrm{~K} / \mathrm{AKT}$ & 49 \\
\hline Piperlongumine & Multiple pathways & 50 \\
\hline FOXO4-DRI peptide & p53 / p21 / serpin & 51 \\
\hline \multicolumn{3}{|l|}{ SENOMORFICS } \\
\hline NBD peptide & IKK / NFB pathway & 52 \\
\hline JAK inhibitor (ruxolitinib) & JAK (Janus kynase) pathway & 53 \\
\hline ESC-CM & PDGF / FGF pathway & 54 \\
\hline Mmu-miR-291a-3p & TGFBR2 / p21 pathway & 55 \\
\hline
\end{tabular}




\section{Senotherapeutics}

It has been shown that accumulation of senescent cells has a causal role in the aging of organs and organisms, and in age-related diseases. Therefore, most therapeutic approaches to the slowing down of various aging phenotypes and related comorbidities are based on preventing the accumulation and elimination of senescent cells with so-called senoterapeutics.

The fundamental mechanisms of activity of senoterapeutics include a) on one hand, selective killing of senescent cells (senolytics), where the main goals are the biological pathways of cell senescence processes; b) on the other hand, the suppression of SASP factors (senomorphics), i.e. the prevention of possible pro-inflammatory effect by targeting regulators and effectors of $\mathrm{SASP}^{39,40}$. For both strategies already there are convincing results obtained on experimental model systems. In the development of senoterapeutics there is also c) a strategy to stimulate the immune response to the senescent cells which should result in their removal from the tissue $e^{41,42}$.

The main positions of the activity of the senotherapeutics are shown schematically in Figure 2. and in Table 1. are examples of the group of senolitics and senomorphyc compounds, some of which are described in more detail below.

Within the previously mentioned strategy c) - stimulation of senescent cell clearance by the immune system - the most commonly mentioned is the potential use of anti-DPP4 (cell surface protein CD26 or dipeptidyl peptidase 4, DPP4) antibody ${ }^{56}$ and monoclonal antibody to $\mathrm{CD} 9^{57}$ as targets for the promotion of antibody-dependent cell-mediated cytotoxicity (ADDC) - dependent on antibody to senescent cells.

There are several classes of senolitics which include, for example, BCL-2 family proteins, heat shock proteins (HSP90) inhibitors, p53 / p21 and PI3K / AKT pathways inhibitors, receptor kinase inhibitors, histone deacetylase (HDAC) inhibitors, natural compounds, etc. Currently, the most interesting informations are about senolytics directed against members of the BCL-2 protein family, eg. BCL-W and BCL-XL ${ }^{58}$, thus targeting the resistance of senescent cells to apoptosis, so that their destruction leads to the activation of programmed cell death ${ }^{59}$ and changes in the autophagy process. The first described senolytics were dasatinib (under the name SPRYCEL was used in the treatment of adult patients with chronic myeloic leukemia; its targets are several protein tyrosine kinases (eg. BCR/Abl c-KIT and some members of Scr family), and herbal flavonoid quercetin involving the PI3K / AKT pathways as a molecular target ${ }^{60,61}$. Dasatinib effectively reduces the viability of senescent cells in vitro and is also confirmed by its in vivo effectiveness. The combination of these compounds with senolytic action has also been used in investigations.

Navitoclax (i.e. ABT 263) is considered like senotherapeutic of powerul senolytic activity ${ }^{62}$. It is directed to inhibition of specific BCL-XL and BCL-W members of the family of BCL-2 apoptotic proteins. Navitoclax is also used in the treatment of some malignant conditions ${ }^{62}$, but its use is limited due to adverse thrombocytopenic and neutropenic effects. Navitoclax analogs such as A1331852, A1155453, ABT 737 also target members of the BCL-2 protein family in both in vitro and in vivo models ${ }^{42,49}$. In addition to quercetin, the therapeutic potential of other phytochemicals, such as flavonol fisetin and piperlongumine alkaloids, is also examined. The mechanism of action of the fisetin includes the PI3K / AKT / mTOR pathway, and the piperlongumine appears to include the NF- $\bigotimes \mathrm{B}$ pathway ${ }^{50}$. According to literature, these compounds also exhibit senolytic and senomorphic activity, depending on the type of cells used in the study ${ }^{49}$. Of the natural compounds in the literature are also mentioned flavonoids kaempferol, apigenin, some compounds from the polyketide group and resveratrol ${ }^{63}$.

The potential for senolytic activity is shown by inhibitors such as HSP90, geldanamycin, benzoquinone antineoplastic antibiotic and its analogs 17-AAG and 17-DMAG ${ }^{46}$, an inhibitor of interactions of MDM2 / p53 proteins, as well as UBX0101, a small molecule that is already in phase 1 clinical trial in patients with osteoarthritis of the knee ${ }^{64}$. Furthermore, the senolytic activity of HDAC inhibitor - panobinostat, was demonstrated in senescent lung cancer cells and in the cell line of head and neck squamous cell carcinoma ${ }^{65}$. Panabinostat inhibits the interaction of FOXO4 and $\mathrm{p} 53$ and induces apoptosis in the IMR $90^{47}$ population, as well as in other types of senescent cells ${ }^{51}$.

As already mentioned, senescent cells differ regarding to their characteristics, in concordance to specific cellular or tissue factors, for example expression of different markers, secretion of various SASP factors, and using different SCAP pathways. Therefore it can be assumed that other classes of senolytics will be discovered in the future, and that the combination of senotherapeutics will be more acceptable for the elimination of senescent cells from different tissues in vivo ${ }^{40,46}$.

Initial studies with senolytics are promising but there is no doubt that there are still many unknowns about their effectiveness. According to research on the osteoarthritis model, it has been shown that after discontinuation of senolytics, senescent cells may reappear ${ }^{64}$.

A group of senotherapeutics that suppresses or modulates secretory phenotypes without inducing apoptosis and in a certain way interferes with "inflammaging" i.e. with senoinflamamtion are senomorphic drugs. These are, for example, compounds targeting senoinflamation $^{66}$, telomerase activators ${ }^{42}$, mimetics of caloric restriction ${ }^{67}$, activators of sirtuins ${ }^{68}$ and autophagy ${ }^{69}$, mTOR inhibitors ${ }^{70}$, antioxidants and other compounds. As indicated in Table 1, the mechanisms of the activity of the senomorphic drugs include inhibitors of NF囚B and I $\otimes B$ kinase (IKK) ${ }^{52}$, Janus kinase pathway inhibitors (JAK) ${ }^{52}$, inhibitors of PDGF / FGF pathway and TGFBR2 / p21 pathway ${ }^{42}$. It has been shown that rapamycin, a drug currently used to suppress immunity in transplanted organ patients, acts as a SASP suppressant, using a mechanism that includes the inhibition of mTOR kinase, associated 
with the inclusion of Nrf2-dependent and independent modules ${ }^{71}$. Senomorphic potential is further attributed to some herbal compounds such as quercetin-3-O-beta-D glucuronide, juglanin and quercetagetin 3,4, -dimethyl ether ${ }^{72,73,74}$.

As already mentioned, one of the ways of removing senescent cells to maintain tissue homeostasis in physiological, pathological and aging conditions is also a cooperation with immune system ${ }^{75}$. As an alternative therapeutic approach to the removal of senescent cells, an immune therapy strategy, i.e., antibody-mediated targeted drug delivery to senescent cells, is also established. It is also considered that imunotherapeutics for malignant diseases that are already in development could also be used for targeting senescent cells in the aging process and with aging-related diseases (Alzheimer's, diabetes, pulmonary fibrosis, and other diseases). Expression of DPP4 on the membranes of senescent fibroblast was revealed in recent studies by Kim EC. et al. ${ }^{42}$. Also, it was highlighted the possibility of the use of DPP4 as a target for the promotion of antibody-dependent cell-mediated cytotoxicity against senescent cells ${ }^{56}$. Another goal of the immunotherapy strategy is the expression of the NKG2D receptor (Natural killer group 2D) on senescent cells, recognized by NK cells that also remove them. The tumor cell removal strategies are also developed on this principle ${ }^{76}$.

In addition to investigations that, based on the new molecular knowledge of senescent cells and mechanisms of their formation, have the goal of detecting appropriate therapeutic goals, there is also a recent investigation of already existing licensed drugs such as senolytics or senomorphic compounds. Hence, these drugs would have an additional purpose. Namely, animal model testing, by the implementation of new bioinformatics approaches, has shown that some existing drugs are effective in prolonging life expectancy ${ }^{48}$. Presently, this group of therapeutics includes, for example, multipurpose drug ruxolitinib, antineoplastic panobinostat, glucocorticoids, opioid loperamide, antipsychotic fluspirilen, antidiabetics metformin and acarbose, immunosuppressive drug sirolimus (rapamycin), tanespimycin-analogue geldanamycin, antineoplastic antibiotics, polyphenolic compound resveratrol etc. ${ }^{18,48,63,77}$. According to present knowledge, it seems that tanespimycin has the greatest potential for senotherapeutic activity.

The process of discovering the senolytic or senomorphic potential of a compound in vitro and in vivo is a complex process that includes, for example, detailed knowledge of molecular-level mechanisms, cell / tissue types used in the study, senescence induction method, knowledge of potential indirect effects on the immune system, etc. ${ }^{40}$. In order to reliably monitor the effects of potential senotherapeutics, special efforts are made to identify the specific markers of senescent cells and to optimize sensitive, precise and simple methods for their determination in biological samples (serum, plasma, lymphocytes, urine). According to the American Federation for Aging Research (AFAR), the criteria to be met by aging markers are: to predict the rate of aging, to follow the basic aging process, to produce the test not harmful to the examinees and to be applicable in humans and animals ${ }^{78}$. Markers currently in use can generally be divided into molecular aging markers that may reflect molecular mechanisms of aging (eg. markes of DNA and chromosome, RNA and transcriptome, markers of oxidative stress, cell senescence, metabolism etc.) and phenotypic markers which are non-invasive and are easily available (eg. anthropometric features, body mass index, muscle mass, etc. $)^{78}$.

There are several review articles that mention a greater number of aging markers, including cell senescence $\mathrm{e}^{78,79,80,81}$. For the time being, however, none of the markers does not meet the criteria of the ideal marker, and therefore, in principle, it is recommended to use marker panels. Accordingly, studies under the MARK-AGE project are under way to identify a set of markers that will best indicate the biological age of the person ${ }^{82}$. In scientific research, the most commonly used is the determination of SAD-galactosidase activity ${ }^{83,84}$ and the method of shortening the telomeres ${ }^{85,86}$.

\section{CONCLUSION}

Although knowledge in the field of investigations of aging, particularly the role of cell senescence in the aging process of the organism, have been extended to the molecular level in recent years, it can be said that they are still almost at the very beginning and far from complete understanding. In the future, many new discoveries are expected and an integrative approach will be needed for scientists from the fields of genetics, biology and evolution.

Can elimination of senescent cells be an intervention that will significantly extend human life? Detection and development of senotherapeutics is definitely a new and very promising field of drug research because today, along with traditional methodologies (eg. transgenic animals, in vivo models of illness etc.), various new technological approaches are available, such as sophisticated chemistry biology techniques, reporpose of already existing drugs, bioinformatics. Due to the numerous possible overlapping of the mechanisms of functioning, caution is required when interpreting their actions, selectivity and specificity and ultimately the efficacy of senotherapeutics. It should also be borne in mind that senescent cells, in addition to adverse effects, also have physiological functions, and that massively removing of such cells could disrupt the integrity of a tissue. For now, there are insufficient knowledge on the links between molecular, cellular and physiological aspects of the removal of senescent cells. Therefore, the question of whether the elimination of senescent cells can be effective in the extension of life span remains open. It is indisputable that the scientific field of aging testing and age-related diseases as well as the field of development of senotherapeutics will further meet with numerous challenges. 
AUTHOR CONTRIBUTIONS:

All authors listed have made a substantial, direct and intellectual contribution to the work, and approved it for publication.

\section{LITERATURE:}

1. Christensen K, Doblhammer G, Rau R, Vaupel J.W. Ageing populations: The challenges ahead. Lancet 2009;374:1196-208.

2. World Health Organization. World report on ageing and health. Geneva: World Health Organization. 2015; p 40.

3. Smith MJ. Review Lectures on senescence: I The Causes of Aging. Sci Aging Knowl Environ 2001; 1: p.cp 10.

4. Sgarbieri VC, Bertoldo Pacheco MT. Healthy human aging: intrinsic and environmental factors. Braz J Food Technol 2017;20:123.

5. Harman D. Aging - A theory based on free-radical and radiation-chemistry. J Gerontology 1956;11(3):298-300.

6. Ursini F, Maiorino M, Forman HJ. Redox homeostasis: The golden mean of healthy living. Redox Biology 2016;8:205-15.

7. Theurey P, Pizzo P. The Aging Mitochondria. Genes 2018;9(22):113.

8. Xia S, Zhang X, Zheng S, Khanabdali R, Kalionis B, Wu et al. An update on Inflammaging: Mechanisms, prevention, and treatment. J Immun Res 2016; 8426874; 1-12.

9. Franceschi C, Garagnani P, Vitale G, Capri M, Salvioli S. Inflammaging and 'Garb-aging' Trends in Endocrinology and Metabolism. 2017;28(3):199-212.

10. Gladyshev VN. Aging: Progressive decline in fitness due to the rising deleteriome adjusted by genetic, environmental, and stochastic processes. Aging Cell 2016;15(4):594-602.

11. de Magalhães JP, Stevens M,Thornton D. The Business of Anti-Aging Science.Trends in Biotechnology 2017;35(11):1062-73. 12. Jensen GL, Mcgee M, Binkley J. Nutrition in the elderly. Gastroenterol Clinics of North America 2001;30(2):313-34.

13. Kubben N, Misteli T. Shared molecular and cellular mechanisms of premature ageing and ageing-associated diseases. Nat Rev Molec Cell Biol 2017;18(10):595-609.

14. Quach A, Levine ME, Tanaka T, Lu AT, Chen BH, Ferrucci L, et al. Epigenetic clock analysis of diet, exercise, education, and lifestyle factors. Aging (Albany NY) 2017;9(2):419-46.

15. Blackburn EH, Epel ES, Lin J. Human telomere biology: A contributory and interactive factor in aging, disease risks, and protection. Science 2015;350(6265):1193-98.

16. Liesa M, Shirihai OS. Mitochondrial dynamics in the regulation of nutrient utilization and energy expenditure. Cell Metabolism 2013;17(4):491-506.

17. Kaushik S, Cuervo AM. Proteostasis and aging. Nature Medicine 2015;21(12):1406-15.

18. Barzilai N, Crandall JP, Kritchevsky SB, Espeland MA. Metformin as a tool to target aging. Cell Metabolism 2016;23(6):10601065 .
19. Saxton RA, Sabatini DM. mTOR Signaling in growth, metabolism, and disease. Cell 2017;168(6):960-76.

20. Bonkowski MS, Sinclair DA. Slowing ageing by design: The rise of $\mathrm{NAD}(+)$ and sirtuin activating compounds. Nat Rev Molec Cell Biol 2016;17(11):679-690.

21. Ren RT, Ocampo A, Liu GH, Belmonte JCI. Regulation of stem cell aging by metabolism and epigenetics. Cell Metabolism 2017;26(3):460-74.

22. Oh J, Lee YD, Wagers AJ. Stem cell aging: Mechanisms, regulators and therapeutic opportunities. Nature Medicine 2014;20(8):870-80.

23. Muñoz-Espín D, Serrano M. Cellular senescence: from physiology to pathology. Nat Rev Mol Cell Biol. 2014;15(7):482-96.

24. Demaria M, Ohtani N, Youssef SA, Rodier F, Toussaint W, Mitchell JR, et al. An essential role for senescent cells in optimal wound healing through secretion of PDGF-AA. Dev Cell 2014;31(6):722-33.

25. Bhatia-Dey N, Kanherkar RR, Stair SE, Makarev EO, Csoka $\mathrm{AB}$. Cellular senescence as the causal nexus of aging. Frontiers in Genetics 2016;7:1-13.

26. Collado M, Serrano M. Senescence in tumours: evidence from mice and humans. Nat Rev Cancer 2010;10(1):51-7.

27. McHugh D, Gil J. Senescence and aging: Causes, consequences, and therapeutic avenues. J Cell Biol 2018;217(1):65-77.

28. Zeng S, WH Shen, Liu L. Senescence and cancer. Cancer Transl Med 2018;4(3):70-4.

29. Kang HT, Lee CJ, Seo EJ, Bahn YJ, Kim HJ, Hwang ES. Transition to an irreversible state of senescence in HeLa cells arrested by repression of HPV E6 and E7 genes. Mech Ageing Dev 2004;5(1): 31-40.

30. Matjusaitis M, Chun G, Sarnoski EA, Stolzing A. Biomarkers to identify and isolate senescent Cells. Ageing Res Rev 2016; 29:1-12. 31. Lasry A, Ben-Neriah Y. Senescence-associated inflammatory responses: aging and cancer perspectives. Trends Immunol 2015;36: 217-28.

32. Herranz N, Gil J. Mechanisms and functions of cellular senescence. J Clin Invest 2018;128(4):1238-46.

33. Kirkland JL, Tchkonia T. Cellular Senescence: A Translational Perspective. EBioMedicine 2017;21:21-28.

34. Childs BG, Baker DJ, Kirkland JL, Campisi J, van Deursen JM. Senescence and apoptosis: Dueling or complementary cell fates? EMBO Reports 2014;15(11):1139-53.

35. Perez Mancera PA, Young AR, Narita M. Inside and out: the activities of senescence in cancer. Nat Rev Cancer 2014;4(8):547-58. 36. He SH, Sharpless NE. Senescence in health and disease. Cell 2017;169(6):1000-11. 
37. Rizvi SI, Çakatay U, Editors. Molecular Basis and Emerging Strategies for Anti-aging Interventions . Springer Nature Singapore Pte Ltd. 2018 .

38. Rattan SIS. Nutrition and food for health and longevity. Int J Nutr Pharm Neur Dis 2015;5:45.

39. Childs BG, Gluscevic M, Baker DJ, Laberge RM, Marquess D, Dananberg J, et al. Senescent cells: an emerging target for diseases of ageing. Nat Rev Drug Discov 2017;16(10): 718-35.;

40. Niedernhofer LJ, Robbins PD. Senotherapeutics for healthy ageing. Nature Rewiews/Drug Discovery 2018;17:1-3 ( correspondence 377).

41. Ovadya Y, Krizhanovsky V. Strategies targeting cellular senescence. J Clin Invest 2018;128(4):1247-54.

42. Kim EC, Kim JR. Senotherapeutics: emerging strategy for healthy aging and age-related disease. BMB Rep 2019;52(1):47-55. 43. Yosef R, Pilpel N, Tokarsky-Amiel R, Biran A, Ovadya Y, Cohen $S$, et al. Directed elimination of senescent cells by inhibition of BCL-W and BCL-XL. Nat Commun 2016; 7: 1-11.

44. Chang J, Wang Y, Shao L, Laberge RM, Demaria M, Campisi J, et al. Clearance of senescent cells by ABT263 rejuvenates aged hematopoietic stem cells in mice. Nat Med 2016;22:78-83.

45. Hwang HV, Tran DT, Rebuffatti MN, Li C-S, Knowlton AA .Investigation of quercetin and hyperoside as senolytics in adult human endothelial cells. PLoS One 2018;13(1):1-14.

46. Ogrodnik M, Salmonowicz H, Gladyshev VN. Integrating cellular senescence with the concept of damage accumulation in aging: Relevance for clearance of senescent cells. Aging Cell 2018;e12841.

$1-21$.

47. Fuhrmann-Stroissnigg H, Ling YY, Zhao J, McGowan SJ, Zhu Y, Brooks RW, et al. Identification of HSP90 inhibitors as a novel class of senolytics. Nat Commun 2017; 8:1-14.

48. Fuentealba M, Donertas HM, Williams R, Labbadia J, Thornton JM, Partridge L. Using the drug a -protein interactome to identify anti-ageing compounds for humans. PLoS Comput Biol 2019;15(1):1-17

49. Zhu Y, Doornebal EJ, Pirtskhalava T, Giorgadze N, Wentworth $\mathrm{M}$, Fuhrmann-Stroissnigg $\mathrm{H}$, et al. New agents that target senescent cells: the flavone, fisetin and the BCL-XL inhibitors A1331852,

A1155453. Aging (Albany NY) 2017;9(3):955-63.

50. Wang Y, Chang J, Liu X, Zhang X, Zhang S, Zhang X, et al. Discovery of piperlongumine as a potential novel lead for the development of senolytic agents. Aging (Albany NY) 2016;8(11):291526.

51. Baar MP, Brandt RMC, Putavet DA, Klein JDD, Derks KWJ, Bourgeois BRM, et al. Targeted Apoptosis of Senescent Cells Restores Tissue Homeostasis in Response to Chemotoxicity and Aging. Cell 2017,169:132-47.

52. Tilstra JS, Robinson AR, Wang J, Gregg SQ, Clauson CL, Reay $\mathrm{DP}$, et al. NF- $\bigotimes \mathrm{B}$ inhibition delays DNA damage-induced senescence and aging in mice. J. Clin. Invest. 2012;122.2601-12.
53. Xu M, Tchkonia T, Ding H, Ogrodnik M, Lubbers ER, Pirtskhalava T, et al. JAK inhibition alleviates the cellular senescence-associated secretory phenotype and frailty in old age. Proc. Natl Aca Sci USA 2015;112:E6301-E10.

54. Bae YU, Choi JH, Nagy A, Sung HK and Kim JR. Antisenescence effect of mouse embryonic stem cell conditioned medium through a PDGF/FGF pathway. FASEB J 2016;30: 1276-86. 55. Bae YU, Son Y, Kim CH, Kim KS, Hyun SH, Woo HG, et al. Embryonic stem cell-derived mmu-miR-291a-3p inhibits cellular senescence in human dermal fibroblasts through the TGF--receptor 2 pathway. J Gerontol A Biol Sci Med Sci 2018; Series A, gly208. 56. Kim KM, Noh JH, Bodogai M, Martindale JL, Yang X, Indig FE, et al. Identification of senescent cell surface targetable protein DPP4. Genes Dev 2017;31:1529-34.

57. Thapa RK, Nguyen HT, Jeong JH, Kim JR, Choi HG, Yong CS, et al. Progressive slowdown/prevention of cellular senescence by CD9- targeted delivery of rapamycin using lactose-wrapped calcium carbonate nanoparticles. Sci Rep 2017;7:1-11.

58. Lujambio A, Akkari L, Simon J, Grace D, Tschaharganeh DF, Bolden JE, et al. Non-cell-autonomous tumor suppression by $\mathrm{p} 53$. Cell 2013;153:449-60.

59. Zhu Y, Tchkonia T, Fuhrmann-Stroissnigg H, Dai HM, Ling YY, Stout MB, et al. Identification of a novel senolytic agent, navitoclax, targeting the Bcl-2 family of anti-apoptotic factors. Aging Cell 2016;15(3):428-35.

60. Keating, G. M. Dasatinib: A review in chronic myeloid leukaemia and Ph+ acute lymphoblastic leukaemia. Drugs 2017;77:85-96. 61. Zhu Y, Tchkonia T, Pirtskhalava T, Gower AC, Ding H, Giorgadze N, et al. The Achilles' heel of senescent cells: from transcriptome to senolytic drugs. Aging Cell 2015;14:644-58.

62. Rudin CM, Hann CL, Garon EB, Ribeiro de Oliveira M,

Bonomi PD, Camidge DR, et al. Phase II study of single-agent navitoclax (ABT-263) and biomarker correlates in patients with relapsed small cell lung cancer. Clin Cancer Res 2012;18 (11):3163-9.

63. Myrianthopoulos V. The emerging field of senotherapeutic drugs. Future Med Chem 2018;10(20): 2369-72.

64. Jeon OH, Kim C, Laberge RM, Demaria M, Rathod S, Vasserot AP, et al. Local clearance of senescent cells attenuates the development of post-traumatic osteoarthritis and creates a pro-regenerative environment. Nat Med 2017;23:775-81.

65. Samaraweera L, Adomako A, Rodriguez-Gabin A, McDaid HM. A Novel Indication for Panobinostat as a Senolytic Drug in NSCLC and HNSCC. Sci Rep 2017;7: 1-11.

66. Soto-Gamez A, Demaria M. Therapeutic interventions for aging: the case of cellular senescence. Drug Discov Today 2017;22:786-95. 67. Roth GS and Ingram DK. Manipulation of health span and function by dietary caloric restriction mimetics. Ann N Y Acad Sci 2016;1363:5-10.

68. Hubbard BP and Sinclair DA. Small molecule SIRT1 activators for the treatment of aging and age-related diseases. Trends Pharma- 
col Sci 2014;35(3):146-154.

69. Nakamura S, Yoshimori T. Autophagy and Longevity . Mol Cells 2018; 41:65-72.

70. Lamming DW, Ye L, Sabatini DM and Baur JA. Rapalogs and mTOR inhibitors as anti-aging therapeutics. J Clin Invest 2013;123:980-9.

71. Wang R, Yu Z, Sunchu B, Shoaf J, Dang I, Zhao S, et al. Rapamicin inhibits the secretory phenotype of senescent cells by a Nrf2-independent mechanism. Aging Cell 2017;16(3):564-74. 72. Yang HH, Hwangbo K, Zheng MS, Cho JH, Son JK, Kim HY, et al. Quercetin-3-O-beta-D-glucuronide isolated from Polygonum aviculare inhibits cellular senescence in human primary cells. Arch Pharm Res 2014;7:1219-33.

73. Yang HH, Hwangbo K, Zheng MS, Son JK, Kim HY, Baek SH, et al. Inhibitory effects of juglanin on cellular senescence in human dermal fibroblasts. J Nat Med 2014;68:473-80.

74. Yang HH, Zhang H, Son JK and Kim JR. Inhibitory effects of quercetagetin 3,4'-dimethyl ether purified from Inula japonica on cellular senescence in human umbilical vein endothelial cells. Arch Pharm Res 2015;38:1857-64.

75. Burton DGA, Stolzing A. Cellular senescence: Immunosurveillance and future immunotherapy. Ageing Res Rev 2018;43:17-25. 76. Sagiv A, Burton DGA, Moshayev Z, Vadai E, Wensveen F, Ben-Dor S, et al. NKG2D ligands mediate immunosurveillance of senescent cells. Aging (Albany NY) 2016; 8: 328-44.

77. Mannick JB, Del Giudice G, Lattanzi M, Valiante NM, Praestgaard J, Huang B, et al. mTOR inhibition improves immune function in the elderly. Science Translational Medicine 2014; 6 (268):pp268ra179.

78. Xia X, Chen W, McDermott J, Jackie Han JD. Molecular and phenotypic biomarkers of aging. Version 1. F1000Res. 2017; 6: 860. 79. Dodig S, Čepelak I, Pavić I . Hallmarks of senescence and aging. Biochem Med 2019; in press

80. Wang AS, Dreesen O. Biomarkers of Cellular Senescence and Skin Aging. Front. Genet 2018; 9:1-14.

81. Engelfriet PM, Jansen EHJM, H. Picavet SJ, Dollé MET. Biochemical Markers of Aging for Longitudinal Studies in Humans. Epidemiol Rev 2013;35:132-51.

82. Bürkle A, Moreno-Villanueva M, Bernhard J, Blasco M, Zondag G, Hoeijmakers JH, et al. MARK-AGE biomarkers of ageing. Mech Ageing Dev 2015; 151: 2-12.

83. Biran A, Zada L, Abou Karam P, Vadai E, Roitman L, Ovadya $\mathrm{Y}$, et al. Quantitative identification of senescent cells in aging and disease. Aging Cell. 2017;16:661-71.

84. Noppe G, Dekker P, de Koning-Treurniet C, Blom J, van Heemst D, Dirks RW. Rapid flow cytometric method for measuring senescence associated $\bigotimes$-galactosidase activity in human fibroblasts. Cytometry A 2009;75:910-16.

85. Bernadotte A, Mikhelson VM, Spivak IM. Markers of cellular senescence. Telomere shortening as a marker of cellular senescence. Aging (Albany NY). 2016;8(1): 3-11.

86. Montpetit AJ, Alhareeri AA, Montpetit M, Starkweather AR, Elmore LW, Filler K, et al. Telomere length: a review of methods for measurement. Nurs Res. 2014;63:289-99. 